UDK 322

\title{
PROSPECTS OF AGRICULTURAL LAND USE FORMATION IN THE CONDITIONS OF INTRODUCTION OF THE AGRICULTURAL LAND \\ MARKET IN UKRAINE \\ H.M KOLISNYK
}

\author{
Phd of Economic Sciences, Senior Lecturer of the Department of Land \\ Resources Management NULES of Ukraine \\ I. V Trokhymenko \\ Master of the Department of Land Resources Management NULES of \\ Ukraine \\ hryhoriikolisnyk@gmail.com \\ igortrohimenko7@gmail.com
}

\begin{abstract}
The evolution of agricultural land use development in Ukraine has been studied. The main factors influencing the land market on the formation of agricultural land use are identified, they include: the number of potential buyers (land users) and sellers, the expiration of the lease, the structure of the land bank of the agricultural enterprise (lease, ownership), land consolidation based on land purchase and sale. The article, based on the example of Narizhanska village council of Poltava district, established that only 30 percent of landowners would be able to sell their land plots in the first 2 years due to the expiring lease agreement.
\end{abstract}

The authors study the factors influencing the efficiency of agricultural land use in the land market, the main ones are: disruption of crop rotation, excessive agricultural development and plowing, low rents and competition of land users, a small number of small land uses with poor financial stability, destructive changes -climatic conditions, lack of effective tools for termination of lease agreements, lack, to a large extent, of information on territorial restrictions in the State Land Cadastre and more.

The article proposes to make proposals to the regulatory framework in terms of the possibility of one-time termination or re-conclusion of lease agreements due to changes in significant conditions (circulation of agricultural land), which will intensify the sale process, 
increase investment attractiveness of agricultural land use by increasing the portfolio private property, land consolidation, simplification of the land exchange process, involvement of a larger share of credit and financial institutions in the formation of land use, as well as positively affect the welfare of landowners (shares) and more.

The article proposes to ensure the formation of sustainable land use by improving the regulatory framework, ensuring an environmentally friendly structure of sown areas primarily through strengthening the role of landowners, increasing the share of small or medium agricultural land use.

Keywords: agricultural land use, agricultural land market, land lease, landowners, land users

Topicality. The issue of theory and practice of agricultural land use occupies a key place in the agricultural policy of the state because agribusiness is one of the main sources of currency, while agricultural land occupies most of the country. This issue becomes especially acute under the influence of the introduction of the agricultural land market [12].

In the context of today's deteriorating conditions for sustainable development of nature, the widespread predominance of economic priorities over sustainable development and public interests in Ukraine as a whole, it is necessary to make important decisions on ways to introduce the agricultural land market and ensure the necessary institutions for its proper functioning.

Many tasks, including the formation of an effective owner, and others that were set before the land reform have not been completed today, and the opening of the market will take place this year.

Given the above, further research requires theoretical, methodological and practical principles of agricultural land use in the functioning of the market, namely: market limitations; fiscal policy; establishing the necessary initial conditions; fullness of the State Land Cadastre, including restrictions on land use; as well as scientifically sound spatial parameters of land use; guaranteeing competitiveness, etc.

Analysis of recent research and publications. In recent years, research on the introduction of the market for agricultural land is being conducted quite actively. The 
analysis of different stages of transformation of agrarian relations, formation of land uses in market conditions, creation of conditions for ecologically safe, development of lease relations and economically efficient land use in Ukraine is devoted to the works of such scientists D.S. Dobriak, A.H. Martyn, L. Y. Novakovskyi , A.M. Tretiak, M.M. Fedorov and others. Issues of development of the market of agricultural lands - Zaiats V.M. Scientific and methodological principles of transformation of agricultural land use were studied by Kolisnyk H.M. Theoretical and methodological principles of formation of restrictions (encumbrances) in land use were dealt with by J.M. Dorosh, OS Dorosh., R. Levek, O.V. Khodakivska, and I.V. Yurchenko studied the international experience of agricultural land market formation.

Nevertheless, there is a wide range of debatable issues to identify trends in land relations, including scientific and methodological support for the formation of united territorial communities, definition and formation of its own model of agricultural business development, differentiation of methods of state and market regulation of land and property relations.

The aim of the stady. Determining the prospects for the introduction of the market of agricultural land.

Materials and methods of research. The study used a theoretical method, modeling, analysis, synthesis, comparison and generalization. The theoretical basis were regulations, research by scientists on the theoretical and scientificmethodological foundations of the formation and functioning of the agricultural land market. The information base for the analysis and comparison of phenomena was the materials of the State Land Cadastre (Public Cadastral Map).

To achieve the main task of the study of international experience in the functioning of the market of agricultural land, which compared its features. Based on the materials of the State Land Cadastre, the perspective introduction of the agricultural land market and its influence on the formation of agricultural land use are modeled.

Research results and their discussion. As a result of the evolution of land relations, including forms of ownership of land and other natural resources, the main 
forms of ownership have been formed, which are equal to each other - state, communal, private. Depending on the socio-economic development of each territory or country, the relationship between them may vary. At the same time, each form of ownership plays its important function: communal - aimed at organizing the full life of the inhabitants of territorial communities; state - to ensure security, law enforcement, innovation, social, recreational, special functions or to ensure the priority of economic development of various sectors of the economy (land for defense, nuclear energy, natural resources, unsuitable areas for economic activity, etc.); private - focuses on meeting personal or market priorities [5].

Since each form of ownership has equal rights and common interests of use, they can also be combined into land use to achieve economic, social or environmental goals, and it is believed that only the owner can use their property most effectively. In this aspect, the main tasks of land reform in Ukraine were formed - to create an effective owner. Of course, from the economic point of view, the most approximate form of ownership for the enslavement of economic interests is private, but all forms of ownership have their advantages and disadvantages.

Ukraine's gradual transition to a market economy has led to the need to begin the process of transforming land relations. The process of land privatization has begun. Accordingly, agricultural land use has undergone an evolutionary path in Ukraine, which can be divided into the following stages $[7,8]$ :

state monopoly on land;

land reform (unbundling of lands of collective and state farms); mass privatization of land;

crushing of land;

functioning of agricultural land uses based mainly on lease relations;

formation of full-fledged agricultural land use with the introduction of the circulation of agricultural land.

An important aspect of influencing the development of the land market is the study of international experience in the functioning of the agricultural land market. Summarizing the experience of other countries in the introduction of the land market 
and the state of development of agricultural land use can be identified key characteristics, see table. 1.

Most of the countries with developed economies have a free market for agricultural land, along with this, each country has certain features (restrictions). At the same time, the production of agricultural products from the above list of the country occupies a small part of the total gross product of the country, usually not more than 10 percent. The predominant form of ownership of agricultural land is private ownership. Given the data in Table 1 and the experience of other countries, we can say that despite the reasons, features and path to the introduction of the market of agricultural land in most countries, it operates successfully and is an integral part of the economy, and agricultural land on a number of others are a commodity.

Table. 1 Foreign experience in the functioning of the market of agricultural land

\begin{tabular}{|l|l|l|l|l|l|l|l|}
\hline Country & $\begin{array}{l}\text { Area of } \\
\text { agricultu } \\
\text { ral lands }\end{array}$ & $\begin{array}{l}\text { Presen } \\
\text { ce of } \\
\text { land } \\
\text { marke } \\
\mathbf{t}\end{array}$ & $\begin{array}{l}\text { Market } \\
\text { restrictio } \\
\text { ns }\end{array}$ & $\begin{array}{l}\text { Price, \$ / } \\
\text { ha }\end{array}$ & $\begin{array}{l}\text { Level of } \\
\text { plowing } \\
\mathbf{\%}\end{array}$ & $\begin{array}{l}\text { GDP of } \\
\text { agricult } \\
\text { ural } \\
\text { sector in } \\
\text { the } \\
\text { general } \\
\text { structur } \\
\text { e,\% }\end{array}$ & $\begin{array}{l}\text { Predomina } \\
\text { nt form of } \\
\text { ownership }\end{array}$ \\
\hline England & $36,3 \%$ & + & Present & 23450 & $25,9 \%$ & $0,7 \%$ & proprietary \\
\hline France & $43,18 \%$ & + & Present & 6270 & $33,5 \%$ & $2,3 \%$ & proprietary \\
\hline Netherlands & $54,9 \%$ & + & Present & 68200 & $10,1 \%$ & $1,8 \%$ & proprietary \\
\hline Poland & $47,1 \%$ & + & Present & 10300 & $35,2 \%$ & $3,3 \%$ & proprietary \\
\hline Israel & $24,1 \%$ & + & Present & - & $13,7 \%$ & $2,5 \%$ & proprietary \\
\hline USA & $44,3 \%$ & + & Present & 10200 & $16,6 \%$ & $1,4 \%$ & proprietary \\
\hline Canada & $7,0 \%$ & + & Present & 4450 & $5,0 \%$ & $9,0 \%$ & proprietary \\
\hline Argentina & $54,5 \%$ & + & Present & 14000 & $26,6 \%$ & $8,3 \%$ & proprietary \\
\hline Australia & $53,20 \%$ & + & Present & 1600 & $6,0 \%$ & $3,0 \%$ & proprietary \\
\hline
\end{tabular}


Formed on the basis of materials $[1,9,10]$

Today in Ukraine there are almost 41.4 million hectares of agricultural land, of which 32.7 million hectares are arable land, which is the level of plowing about $54 \%$ in Central Europe - 35\%, which indicates an excessively high level of plowing in Ukraine. It should be understood that 31 million hectares are privately owned, which is 25.3 million landowners and land users, of which 6.9 million are unit holders. At the same time, the structure of agricultural use lands are as follows: cultivated by owners - 29\%, leased - 56, leased from the state - 8 , not cultivated 7 . The area of chernozems, potentially the most attractive for agricultural production according to various sources is 15.6-17.4 million hectares, which is actually half of the arable land. A poll by the Institute of Agrarian Economics of the National Academy of Sciences of Ukraine showed that only 13 percent of Ukrainians plan to sell land from those who inherited it, and only 5 percent who received a share at work. The share of owners who want to start their own business or leave it for their own use is $22 \%$ (who inherited) and 13 (who received it for the first time). The largest number of landowners plan to lease their land, namely $38 \%$ of those who inherited and, accordingly, the first 48 landowners [6]. In this case, we are talking only about intentions, not about the actual sale. In general, the above data indicate restrained expectations of the population regarding the sale of their own land plots.

In addition to the survey data and the intentions of landowners, an objective deterrent to the lease of land, which actually eliminates any desire to sell or increase the cost of rent. We analyzed the data of the State Land Cadastre (Public Cadastral Map) on the duration of land lease on the example of land located in the Narizhanskaya village council of Semenivsky district of Poltava region with the assumption of the shortest possible lease of land (7 years), according to the Law of Ukraine About land lease » $[4,11]$.

The most popular are contracts concluded for 7 years, given the current trends leading to the open market of agricultural land, and consequently the possible 
increase in the cost of land lease, most tenants are already trying to re-sign leases for more than 10 years.

The duration of the lease of land should depend on the intention of the lessee to rationally use the land and the specifics of growing crops. As the moratorium distorts the functioning of the agricultural land market, most private agricultural land is leased. Currently, about 4.7 million private owners (70\% of the total) lease their land to agricultural producers - the total size of the official rental market is about 17 million hectares.

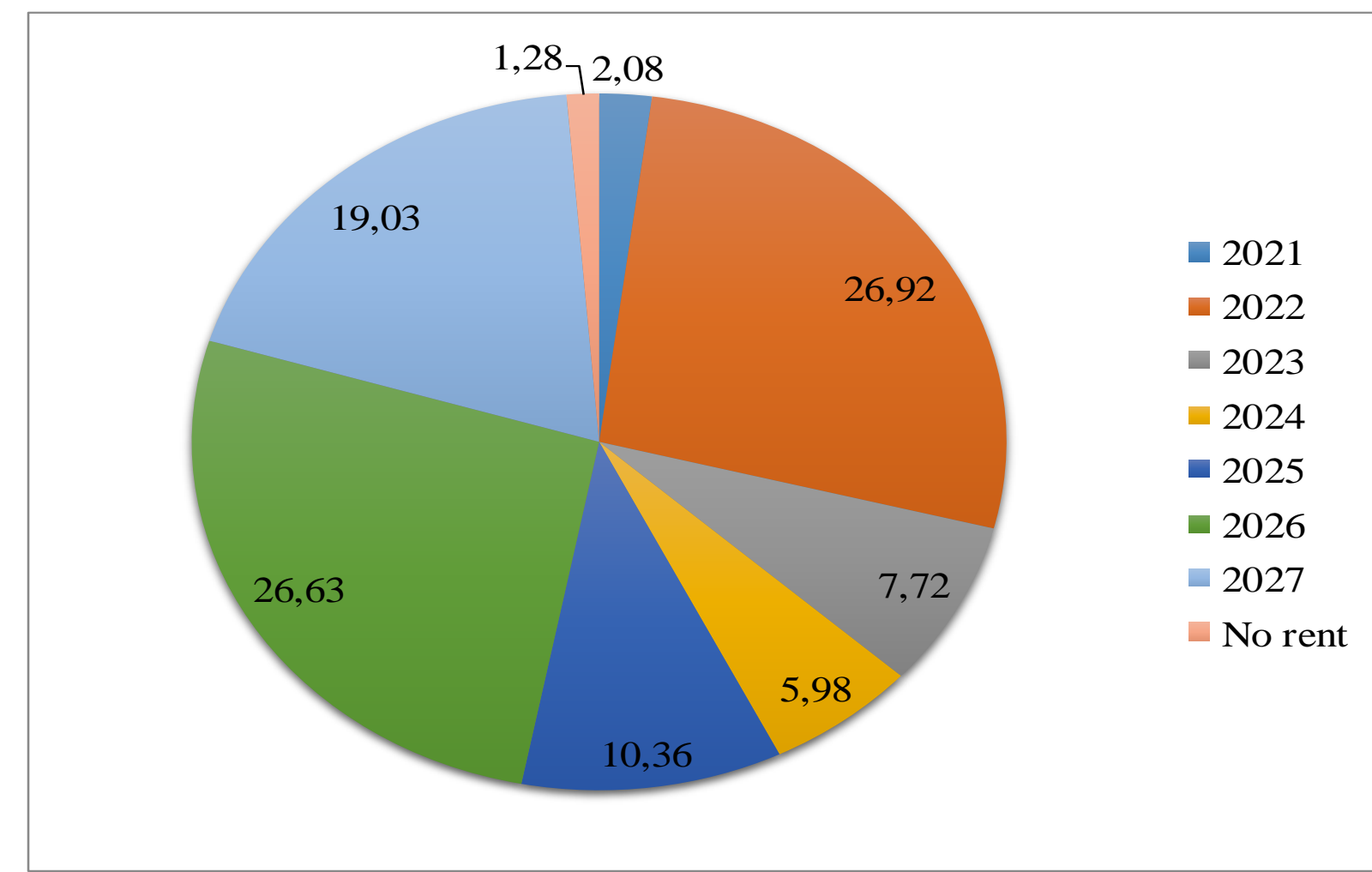

Fig. 1. Term of expiration of lease agreements for agricultural land plots on the territory of Narizhanska village council,\% [Ошибка! Источник ссылки не найден.]

After analyzing agricultural land plots with an area of more than 0.8 hectares on the territory of the community, the results were obtained on the terms of the end of 
the lease of land plots on the territory of Narizhanska village council. This chart highlights the three largest sectors, which correspond to 2022, 2026 and 2027. At the same time, in 2026 and 2027 there are $45.66 \%$ of contracts, if we add 2025 to this figure, we get more than $56 \%$ of contracts whose validity expires in 4-6 years after the introduction of the agricultural land market. That is, from the very beginning of the introduction of the agricultural land market, not all landowners will be able to feel its benefits. Given the above, to create favorable conditions for the formation of a fair and transparent market of agricultural land, we propose to amend the laws of Ukraine the possibility of one-time termination and / or revision of land lease agreements after the launch of the agricultural land market, because there is a situation when someone can sell someone will have to wait for the end of the lease. Such changes will stimulate the market, accelerate the process of land consolidation, increase supply and increase state budget revenues, and so on.

In addition to the expiration dates of leases, the main market factors that will determine the value of land, including leases, are supply and demand. Focusing on the study of the "Institute of Agrarian Economics" NAAS and the time periods of completion of leases, we can talk about a moderate supply of land in the market.

Demand for lease rights will remain stable or grow slowly, but there will be far fewer people willing to buy agricultural land. For example, we analyzed the structure of tenants of land plots (land shares) according to which a sufficient number of potential buyers and / or tenants in the village council, but three tenants have about 67 percent of agricultural land in use (see Fig.2). But it is clear that the mere presence of potential buyers does not make an agricultural enterprise attractive for investment. 


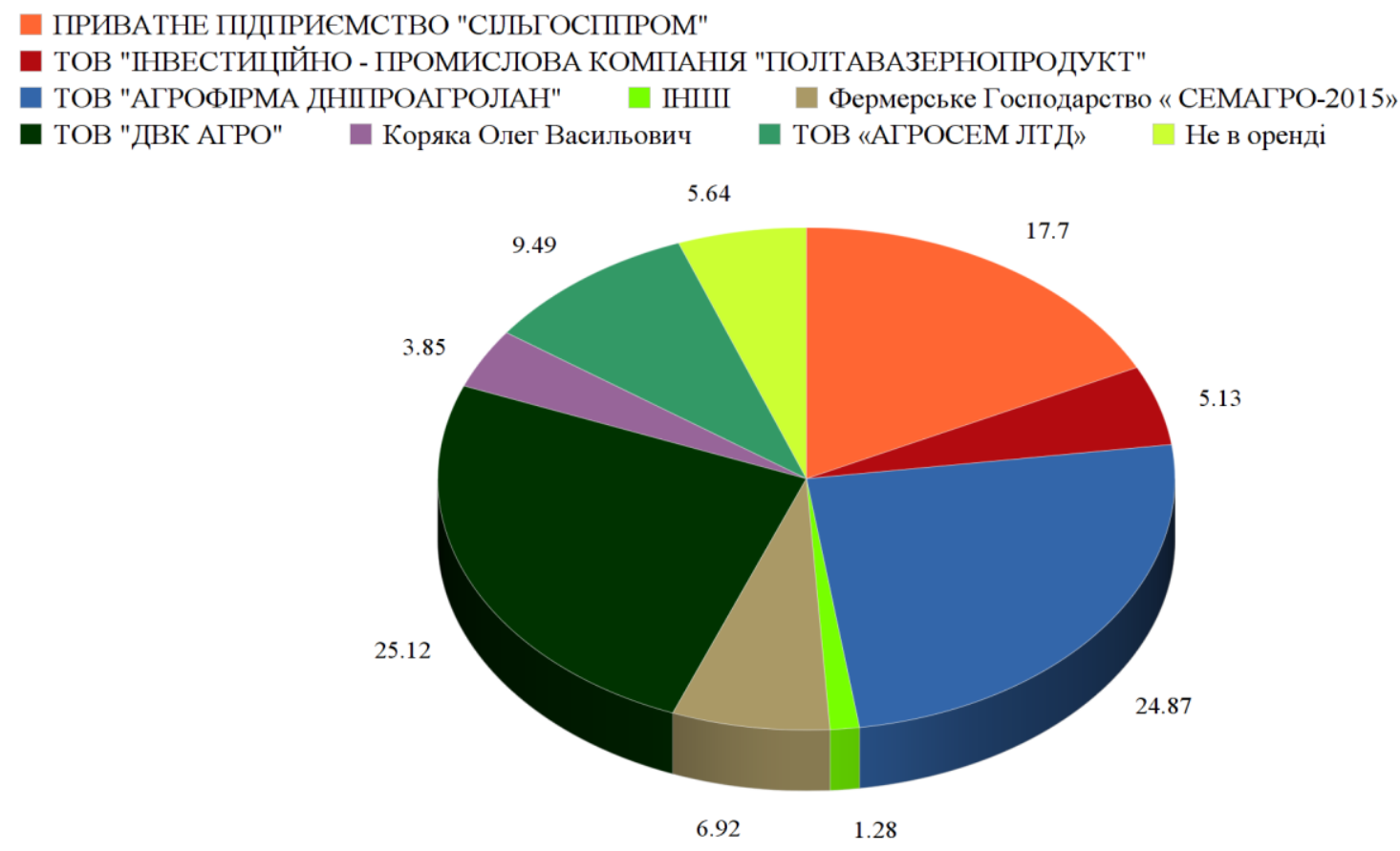

Fig. 2. The structure of leased land in terms of land users, $\%$

To ensure successful investment and the formation of rational land use, it is necessary to ensure the possibility of land consolidation, which will take place transparently, rationally and legally. To date, the state does not actually benefit from the exchange of land between land users, which carries it out without any notarization and payment of taxes, while violating the rights of landlords. In fig. Figure 3 shows a fragment of the field, which most likely confirms this fact (Fig. 3). For example, land plots shown in blue and yellow are leased, but not to the land user whose land plots are highlighted in red, but are most likely to be in his actual land use.

One of the important factors of investment attractiveness of enterprises is its size (market share) and the ratio of assets and liabilities, then the amount of resources involved and the corresponding ratio of own and leased means of production are of key importance. [5]. With regard to agricultural enterprises (land use), the importance is also the value of the share of the land bank, which owns the enterprise, and which is in use, which will certainly affect the investment attractiveness. Also an important role is played by the part of the company's portfolio depending on the 
duration of land lease and the degree of their consolidation, which will take place in parallel with the development of the land market.

In the formation of land use, in addition to the investment portfolio of the enterprise, an important role is played by the existing restrictions on the use of land, which are currently included in the State Land Cadastre in small quantities. The restrictions themselves provide for the regulation of the legal regime of land in the conditions of private property and become especially acute in the conditions of functioning of the market of agricultural lands. At the same time, restrictions on land use and encumbrances on land rights should ensure the harmonization of private, state and public interests, including ensuring environmentally friendly land and nature use. [Ошибка! Источник ссылки не найден.,13]. Today, land users actually level the issue of implementation and compliance with environmental and agro-technical restrictions, especially in the formation and use of agricultural land, which is important for the formation of sustainable agricultural land use.

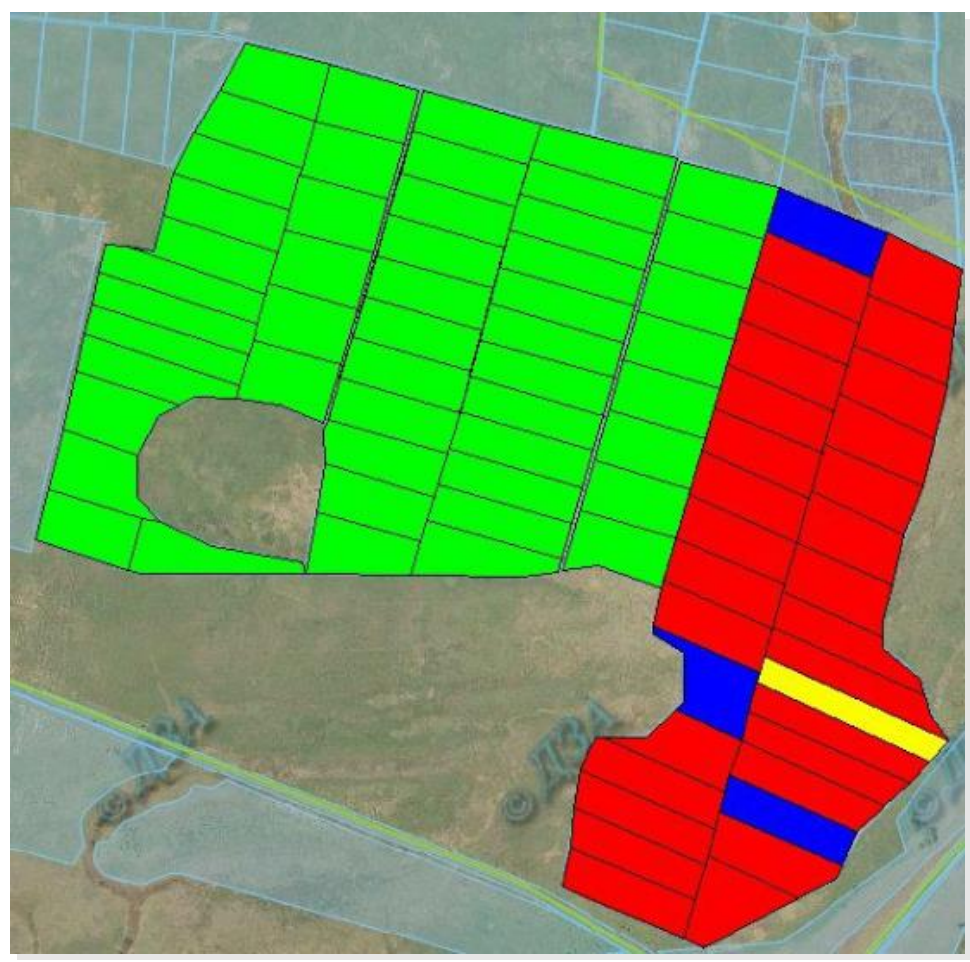

Fig. 3. Schematic representation of a fragment of land use from the Public cadastral map 
In addition to the need to form territorial restrictions in the State Land Cadastre before the introduction of the agricultural land market, important issues that need to be addressed are [15]:

lack of a proper mechanism for the formation of agricultural land use (determining the size of the land bank of the enterprise, the establishment of private property on agricultural land and allowable areas, the establishment of a model of agricultural land use, etc.);

improving the institution of monetary valuation of land, as an integral part of fiscal policy and an element of information support for land transactions;

incomplete entry of information on land plots, their qualitative and quantitative characteristics into the State Land Cadastre;

low cost of rent for agricultural land;

misuse and use of mainly arable land, as well as non-involvement of hayfields, pastures, perennials and other lands that may be involved for multipurpose use;

use of anti-speculative tools;

and other.

At the same time, for the effective formation of agricultural land use in the land market it is necessary to establish: optimal and acceptable values of the structure of sown areas, effective state control over the use and protection of land, conditions for termination of lease agreements. At the same time, perhaps the most important factor in the formation of agricultural land use remains the provision of financial and investment support for agricultural producers in accordance with the chosen model of agricultural land use (Latin American or European).

Examining the value of agricultural land, scientists [14] found that the value of agricultural land can be determined based on the level of value added of agricultural products per unit area, rather than buying and selling land, which deserves attention, because it is an important criterion for agricultural development there is an increase in value added, which reflects the level of land use efficiency, its compliance with modern technologies, the level of use of intellectual potential of land users, competitiveness, etc. 
To ensure the formation of efficient agricultural land use in the functioning of a full-fledged land market, it is necessary to focus on solving the above problems by: improving mechanisms for terminating leases (violation of permissible values of crop rotation, non-compliance with agricultural restrictions, preconditions, as well as the possibility of a one-time termination and / or revision of the terms of the lease agreement in connection with changes in significant conditions, namely the introduction of the land market; withdrawal of degraded and eroded lands from active agricultural land use and their involvement in alternative uses (horticulture, forestry, animal husbandry, renewable energy, bioenergy, etc.); financing of state programs for lending to national agriculture manufacturer; introduction of agro-technical restrictions into the normative-legal base and other.

Conclusions and prospects. The analysis of the structure of land in terms of tenants on the territory of Narizhanska village council showed that only $1.28 \%$ of land located outside the settlements are not leased. Despite the fact that $67 \%$ of leased land is in the use of three land users. Most of the leased land in the community will remain leased for at least 4-6 years, according to previously signed agreements, and with the existing legal framework in the first 2 years only $30 \%$ of landowners will be able to exercise their right to sell agricultural land or renegotiation of contracts. This situation will not fundamentally affect the change of modern approaches to the formation of agricultural land use.

The necessity of making changes to the legislation in terms of the possibility of one-time termination or renegotiation of lease agreements (sale or increase of the lease value) for agricultural land with the introduction of the land market is proved. Eliminating discriminatory approaches to land sales will accelerate the development of agricultural land use in the context of land formation, land consolidation and increase the investment attractiveness of land use, increase tax revenues to budgets at various levels, and increase the share of agricultural land use. The proposed measures should have a positive impact on rural development and the well-being of the rural population, which will bring land reform closer to completion in the context of forming an effective landowner. 
One of the key tasks that need to be addressed is the filling of the State Land Cadastre, including territorial restrictions, which prevents the full functioning of the land market and effective mechanisms for the formation of environmentally friendly and efficient agricultural land use, both agricultural enterprises and land use of citizens.

\section{References}

1. Agricultural land prices by region Available at: https://appsso.eurostat.ec.europa.eu/nui/submitViewTableAction.do.

2. Dobriak D. S., Kolisnyk H.M. (2014) Development of lease relations in the conditions of transformation of agricultural land use in Poltava region. Visnyk Sumskoho natsionalnoho universytetu seriia "Ekonomika i menedzhment", 5, 47-51. [in Ukrainian]

3. Dorosh Y. M., Dorosh O. S. (2017) Formation of restrictions and burdens in land use. Kherson: Vydavets Hrin D.S. [in Ukrainian]

4. Law of Ukraine on the about land lease № 161-XIV. (1998, October 6). Vidomosti Verkhovnoyi Rady Ukrayiny, 46, 280 [in Ukrainian]

5. Zaiats V.M. (2011) Agricultural land market development. Kyiv: NNTs IAE [in Ukrainian]

6. Land Directory of Ukraine 2020 - a database of land funds of the country. Available at: https://agropolit.com/spetsproekty/705-zemelniy-dovidnikukrayini--baza-danih-pro-zemelniy-fond-krayini.

7. Kolisnyk H.M. (2015). Ecological and economic assessment of the transformation of agricultural land use in market conditions. $\mathrm{PhD}$ thesis. Kyiv: NUBiP [in Ukrainian]

8. Kolisnyk H.M. (2016). Scientific and methodological principles of agricultural land use transformation. Zemleustrii, kadastr i monitorynh zemel, 1-2, 101-109 [in Ukrainian] 
9. Levek R., Khodakivska O. V., Yurchenko I. V. (2017) Models of regulation of market circulation of agricultural lands in the countries of the European Union. Ekonomika APK, 10, 5-12 [in Ukrainian]

10. Martyn A.H., Avramchuk B.O. (2016) Improving the agricultural real estate market of Ukraine on the basis of international experience. . Zemleustrii, kadastr i monitorynh zemel, 1-2, 116-127 [in Ukrainian]

11. Official information of the State Land Cadastre (Publichna kadastrova karta Ukrainy). Available at: https://map.land.gov.ua

12. Law of Ukraine on the about modification of some legislative acts of Ukraine concerning conditions of circulation of the lands of agricultural purpose № 552-IX. . (2020, March 31). Vidomosti Verkhovnoyi Rady Ukrayiny, 30, 13 [in Ukrainian]

13. Tretiak A. M., Dorosh Y. M. (2017) Features of the methodological process of formation of restrictions on the use of land and land plots. Zemleustrii, kadastr i monitorynh zemel, 2, 13-19 [in Ukrainian]

14. Tretiak A. M., Tretiak V. M., Tretiak N. A., Polishchuk A. S. (2020) Myths and risks of the law of Ukraine on the circulation of agricultural land. Ahrosvit 11, 35-41 [in Ukrainian]

15. Tretiak A. M. (2019) Land market economics: basic principles of theory, methodology, practice. Lviv: SPOLOM [in Ukrainian]

\section{Г. М. Колісник}

\section{I. В. Трохименко}

ПЕРСПЕКТИВИ ФОРМУВАННЯ СІЛЬСКОГОСПОДАРСЬКИХ

ЗЕМЛЕКОРИСТУВАНЬ В УМОВАХ ЗАПРОВАДЖЕННЯ РИНКУ

СІЛЬСЬКОГОСПОДАРСЬКИХ ЗЕМЕЛЬ В УКРАЇНІ

Анотація. Досліджено еволющію розвитку сільськогосподарського землекористування в Україні. Визначені основні чинники впливу ринку земель на формування сільськогосподарського землекористування, до них варто віднести: кількість потенційних покупців (землекористувачів) та продавиів, 
терміни закінчення договору оренди, структура земельного банку сільськогосподарського підприємства (оренда, власність), консолідація земель на основі купілі-продажу земельних ділянок. $У$ статті, на прикладі Наріжанської сільської ради Полтавського району встановлено, щзо лише 30 відсотків землевласників протягом перших 2 років зможуть продати свої земельні ділянки у зв'язку із закінчується строків договір оренди.

Авторами досліджуються фактори впливу ефективності використання сільськогосподарських землекористувань в умовах функиіонування ринку земель, до основних варто віднести: порушення системи сівозміни, надмірна сільськогосподарська освоєність та розораність, низький рівень орендної плати та конкуренції землекористувачів, незначна кількість дрібних землекористувань із поганою фінансовою стійкістю, диструктивні процеси зміни природно-кліматичних умов, відсутність дієвих інструментів розірвання договорів оренди, відсутність, у значній мірі, внесених відостей про територіальні обмеження до Державного земельного кадастру та інше.

У статті пропонується внесення пропозицій до нормативно-правової бази у частині можливості одноразового розірвання або перезаключення договорів оренди у зв'язку із зміною істотних умов (обіг земль сільськогосподарського призначення), щуо спричинить активізацію процесу продажу, дасть можливість підвищчити інвестиційну привабливість сільськогосподарських землекористувань иляхом збільшенням портфелю приватної власності, консолідації земель, спрощуенням процесу обміну земельними ділянками, залученням більшої частки кредитно-фінансових установ до формування землекористувань, а також позитивно вплине на добробут землевласників земельних часток (паӥв) та інше.

У статті пропонується забезпечити формування сталого землекористування шляхом удосконалення нормативно-правової бази, забезпечення еколого-безпеної структури посівних площ в першу чергу через посилення ролі власників земельних ділянок, збільшення частки дрібних або середніх сільськогосподарських землекористувань. 
Ключові слова: сільськогосподарське землекористування, ринок земель сільськогосподарського призначення, оренда земель, землевласники, землекористувачі

\section{Г. Н. Колесник}

И. В. Трохименко

ПЕРСПЕКТИВЫ

\section{ФОРМИРОВАНИЯ}

\section{СЕЛЬСКОХОЗЯЙСТВЕННОГО ЗЕМЛЕПОЛЬЗОВАНИЯ В УСЛОВИЯХ} ВВЕДЕНИЕ РЫНКА СЕЛЬСКОХОЗЯЙСТВЕННЫХ ЗЕМЕЛЬ В УКРАИНЕ

Аннотация. Исследована эволюиия развития сельскохозяйственного землепользования в Украине. Определены основные факторы влияния рынка земель на формирование сельскохозяйственного землепользования, к ним следует отнести: количество потенциальных покупателей (землепользователей) u продавиов, сроки окончания договора аренды, структура земельного банка сельскохозяйственного предприятия (аренда, собственность), консолидаџия земель на основе покупки-продажи земельных участков. В статье на примере Нарижанського сельского совета Полтавской области установлено, что только 30 процентов землевладельцев в течение первых 2 лет смогут продать свои земельные участки в связи с окончанием сроков договор аренды.

Авторами исследуются факторы влияния эффективности использования сельскохозяйственных землепользования в условиях функиионирования рынка земель, к основным следует отнести: нарушение системы севооборота, чрезмерная сельскохозяйственная освоенность, низкий уровень арендной платы и конкуренции землепользователей, незначительное количество мелких землепользований с плохой финансовой устойчивостью, диструктивние прочессы изменения климатических условий, отсутствие действенных инструментов расторжения договоров аренды, отсутствие, в значительной степени, внесенных видостей о территориальные ограничения $в$ Государственный земельный кадастр и др. 
В статье предлагается внесение предложений в нормативно-правовую базы в части возможности однократного расторжения или перезаключення договоров аренды в связи с изменением сущуественных условий (оборот земли сельскохозяйственного назначения), что повлечет за собой активизацию процесса продажи, позволит повысить инвестицчионную привлекательность сельскохозяйственных землепользования путем увеличением портфеля частной собственности, консолидациии земель, упрощуением процуесса обмена земельными участками, привлечением большей части кредитно-финансовых учреждений к формированию землепользования, а также положительно повлияет на благосостояние землевладельцев земельных долей (паев) и прочее.

В статье предлагается обеспечить формирование устойчивого землепользования путем усовершенствования нормативно-правовой базы, обеспечения эколого-безопасной структуры посевных площзадей в первую очередь усиления роли владельцев земельных участков, увеличение доли мелких или средних сельскохозяйственных землепользований.

Ключевые слова: сельскохозяйственное землепользование, рынок земель сельскохозяйственного назначения, аренда земель, землевладельцьы, землепользователи 